\title{
Voluntary Risk Disclosures of Islamic Financial Institutions: The Role of AAOIFI Standards Implementation
}

\author{
ROMLAH JAFFAR, WARDA ALSHEIKH, MOHAMAT SABRI HASSAN \\ \& MAIZATULAKMA ABDULLAH
}

\begin{abstract}
The implementation of the Accounting and Auditing Organization for Islamic Financial Institutions standards (AAOIFI) can improve the risk disclosure practices of Islamic financial institutions (IFIS) that eventually will reduce information asymmetry and improve the legitimacy. However, its role in the presence of Risk Management Committee (RMC) and Sharia Supervisory Board (SSB) with voluntary risk disclosure (VRD) has not been investigated before. Therefore, this study investigates the role of AAOIFI standards implementation on the relationship between RMC and SSB effectiveness with VRD. The sample consists of 167 firm-year observations of IFIs listed on Saudi Arabian Stock Exchange (TADAWUL) from 2013 to 2017. Data of the study are collected from IFIs annual reports. Agency and signalling theories explain the effect of RMC and SSB on VRD. Additionally, legitimacy theory predicts the moderating role of AAOIFI standards. The results show that the effectiveness of RMC and SSB have a positive effect on the level of VRD. However, the AAOIFI standards implementation does not strengthen the relationship between RMC and SSB effectiveness with the level of VRD. This insignificant finding could be due to the non-mandatory nature of AAOIFI standards implementation in Saudi Arabia. The results of the study enhance the current understanding of the importance of effective RMC and SSB to improve the risk reporting that can reduce information asymmetry and sirengthen legitimacy amongst IFIs. The findings are also useful to regulatory bodies and policymakers to develop the policies and regulations that could influence the disclosure and transparent reporting by listed companies.
\end{abstract}

Keywords: Voluntary risk disclosure; Risk Management Committee; Sharia Supervisory Board; AAOIFI; Saudi Arabia

Voluntary disclosures, which include risk management disclosures by public companies, are vital in order to reduce information asymmetry between managers (agents) and shareholders (principals) (Jensen \& Meckling 1976). The disclosures assist investors, shareholders and debt holders in making beneficial investment decisions, whether they should pursue their investment goals on the basis of that information.

The Risk Management Committee (RMC) is one of the corporate governance mechanisms, which aims to align company policy on risk tolerance with risk appetite and help in formulating risk management financial plans. RMC advises management on risk management strategies and their associated practices. The committee is also responsible for reviewing and approving risk disclosure statements in annual reports and other public documents. Thus, an effective RMC must have members who are expert in risk management and its related issues and processes (Al-Hadi et al. 2016). Past studies confirmed the significant effect of the existence of RMC, as a separate corporate governance committee, on the level of risk management disclosure (e.g. Abdullah et al. 2017; Al-Hadi et al. 2016).

The governance of IFIs and its disclosures are stated in the Accounting and Auditing Organization of Islamic Financial Institutions standards (AAOIFI). The standards discuss the issues relating to Sharia law, auditing, accounting and governance standards, and code of ethics. Specifically, the standards provide a set of acceptable concepts and the level of disclosures that depict the activities of IFIs. The AAOIFI accounting standards provide guidelines on accounting treatment for specific Islamic financial products and mechanisms, and presentation of financial statements that promote transparent reporting practices that alleviate information asymmetries by IFIs (Ullah 2013). Al-Baluchi (2006) showed that the implementation of AAOIFI standards has led to an increase in the level of voluntary disclosure.

The governance standards issued by AAOIFI stipulate on Sharia compliance and supervision process and framework for IFIs. They specify the establishment of Sharia Supervisory Board (SSB), which is an independent body of qualified jurists in fiqh al mu'amalat (Islamic commercial jurisprudence) ${ }^{1}$. SSB formation creates an additional corporate governance layer, which certifies and monitors all financial contracts, transactions and activities of IFIs on behalf of depositors, shareholders and stakeholders. It ensures that the operation of IFIs complies with Sharia law (Alman 2012; Rini 2014). The standards also specify the composition of SSB members. AAOIFI Standard No. 3 indicates the purpose of the Sharia audit to ensure the efficacy of SSB.

In addition to conventional auditing practices, SSB is responsible for monitoring the level of risk management practices and disclosures, whether they are aligned with the guidelines of Sharia law. Previous studies demonstrated that 
SSB is associated with the high voluntary risk disclosure amongst IFIs (El-Halaby \& Hussainey 2016; Farook et al. 2011; Rini 2014; Warda et al. 2020). Therefore, the implementation of AAOIFI standards should strengthen the roles of RMC and SSB in ensuring an adequate level of risk disclosure and transparency practices, which can reduce information asymmetry and improves the legitimacy of IFIs.

Despite the significance of risk disclosure, Saudi Arabian IFIs do not pay adequate attention to this disclosure (Cabedo \& Tirado, 2004). Consequently, regulators and other stakeholders perceived the need to address the determinants for risk disclosures (Al-Maghzom et al. 2016). The current study aims to reinvestigate the relationship between RMC and SSB effectiveness on the level of voluntary risk disclosure among Saudi Arabian IFIs. We extend the findings of prior studies to examine whether the implementation of AAOIFI standards strengthens this relationship. We also advance the literature on the measurement of RMC and SSB effectiveness. We measure them more comprehensively by combining their different characteristics and form an index of their effectiveness. We measure the effectiveness of RMC based on its size, the number of meetings, and members' independence and qualifications. Additionally, we also measure the effectiveness of SSB based on its size, the number of meetings and members' cross membership and reputation.

We use Saudi Arabian IFIs as our sample because the country is currently the leading economy in the Gulf Cooperation Council. The Tadawul All-Share Index of the Saudi Arabian stock market is one of the most highly capitalised stock exchanges in the Arab world. The total value of shares traded annually is approximately SR 60 billion ( $\$ 16$ billion). The country also has the most considerable number of Islamic banks and windows. Therefore, the findings of this study can also be applied to other Islamic countries with smaller economy size. These countries can use these research findings as guidance and references to improve their effectiveness in risk management reporting.

The results of analysis show that the effectiveness of RMC and SSB has a positive effect on the level of voluntary risk disclosure. However, the implementation of AAOIFI standards cannot strengthen the relationship between the effectiveness of RMC and SSB and the level of risk disclosure amongst Saudi Arabian IFIs. The voluntary implementation of AAOIFI standards does not trigger the improvement in the reporting. Therefore, the regulatory bodies or policymakers in the country need to consider the mandatory implementation of the standards to improve the risk reporting of IFIs.

The remaining of this study is organised as follows: The second section presents a review of related literature, followed by the development of the research hypotheses. The third section outlines the research methodology. The fourth section discusses the findings and results. Finally, the fifth section reports the conclusions.

\section{LITERATURE REVIEW AND HYPOTHESIS DEVELOPMENT}

This section discusses basic background information of AAOIFI and the past empirical studies on the voluntary risk disclosure issue. Subsequently, this section elaborates on the development of hypotheses.

\section{ACCOUNTING AND AUDITING ORGANISATION FOR ISLAMIC FINANCIAL INSTITUTIONS STANDARDS (AAOIFI)}

The Accounting and Auditing Organization for Islamic Financial Institutions Standards (AAOIFI) was established in 1990 with the aims to harmonise the reporting by IFIs by supplementing accounting and auditing standards and provide policies and guidelines to assist them in developing Islamic financial services and products that comply with Sharia law. AAOIFI is headed by the General Secretariat comprising of the secretary general and the technical teams. AAOIFI serves as an independent global organisation with 200 adherents from 40 nations comprising central banks, IFIs and other members from the global Islamic banking and finance industry globally (AAOIFI 2016).

AAOIFI prepares and published auditing, accounting, governance, and ethics standards for IFIs. It uses a consultative standard development and revision process before adopting any standard. Currently, AAOIFI has published 95 standards of which 27 are accounting standards, 7 governance standards, 5 auditing standards, 2 ethics standards and 54 are Shari'a rules (AAOIFI 2016).

Most countries that have Islamic financial institutions have adopted AAOIFI accounting standards in financial reporting. The standards have been made mandatory in Syria, Bahrain, Jordan, Sudan, Oman, Pakistan, Indonesia, and Qatar. The standards have also been used in other countries voluntarily for internal reporting such as Saudi Arabia, South Africa, UAE, Malaysia, Brunei, Kuwait, and Egypt among others.

Implementation of AAOIFI standards ensures the adequate disclosure of market and investment risks, which is particularly significant in financial institutions. In line with the Vision $2030^{2}$ adopted by the Saudi Arabia to achieve sustainable development, Saudi Arabian Monetary Authority (SAMA) joined the AAOIFI as a member in October 2017. The collaboration between SAMA and AAOIFI may encourage standardisation of guidelines used to account for Islamic financial operations (Reuters 2017). Prior study by Al-Baluchi (2006) indicated that the implementation of AAOIFI standards increase the motivation for voluntary disclosure. 


\section{RMC EFFECTIVENESS AND VOLUNTARY RISK DISCLOSURES}

Risk Management Committee (RMC) is a part of corporate governance structure that aims at improving the risk assessment, management and disclosures, particularly risk related to businesses and financial tools (Abdullah \& Chen 2010). The committee complements the responsibilities of the audit committee to ensure a more focus reaction to changing business environment and implements risk business strategy for the maximum synergy effect. RMC is also efficient in providing support to monitor and approve risk management policies and practices, and the disclosure of the relevant business risks. The committee is responsible for reviewing and approving risk disclosure statements in any public documents or disclosures (Al-Hadi et al. 2016).

RMC for IFIs faces different and complex agency problems as these institutions are using Mudaraba (profitsharing) contract and prohibit interest-based transactions for mobilising investors fund. This arrangement creates two possible agency conflicts: (1) managers and shareholders' agency problem similar to the one faced in traditional financial institutions, in which managers (agents) behave opportunistically and make decision for their own benefit; and (2) manager and depositors'/investors' agency conflict, in which managers deviate from their fiduciary duty when they invest in non-Sharia compliant activities (Safieddine 2009). Investors anticipate that return from their investment must come from Sharia-compliant investments (Archer et al. 1998). These unique agency relationships in IFIs has heightened the need for effective risk management practice.

According to agency theory, a significant level of voluntary risk disclosure mitigates agency conflict and minimises information asymmetry. Past studies show that RMC can influence IFIs to increase the level of their voluntary risk disclosure (e.g. Abdullah et al. 2017; Al-Hadi et al. 2016; Warda et al. 2020). Signalling theory employs a somewhat different perspective to represent underlying motivation for voluntary risk disclosure. Elzahar and Hussainey (2012) argued that managers convey specific signals through voluntary risk disclosure to potential and current users.

Past studies also show a positive relationship between RMC and risk management disclosure in Australia (Jia et al. 2019). The presence of stand-alone RMC, size of RMC, and human capital of RMC are found useful in assessing the level of risk management disclosure. The sample of the study comprises of the top 100 Australian firms observed from 2010 to 2012. Other studies highlight that the main characteristics of RMC, such as independence of RMC members, their qualifications and size of RMC are associated positively with risk disclosure (Al-Hadi et al. 2016; Warda et al. 2020). Armin (2018) examined the association between corporate governance attributes and risk disclosures of 312 non-financial companies in Indonesia. The results of the study showed a significant association of the existence of RMC and the level of risk disclosure.

In accordance with agency and signalling theories, the current research hypothesises a positive relationship between the level of voluntary risk disclosure and RMC effectiveness. We test this relationship by constructing an index of $\mathrm{RMC}$ effectiveness. The development of this index is elaborated in the next section. On the basis of the above discussion, we propose the following hypothesis:

\section{$H_{1}$ : The effectiveness of RMC has a positive relationship with the level of voluntary risk disclosure amongst IFIs.}

\section{IMPLEMENTATION OF AAOIFI, RMC EFFECTIVENESS AND VOLUNTARY RISK DISCLOSURES}

The majority of Muslim investors prefer Sharia-compliant investments and are sensitive if their investments are not Sharia laws compliance. Therefore, we can interpret that the implementation of AAOIFI standards is necessary in Islamic society and legitimise the establishment of IFIs. The implementation of AAOIFI standards encourages more transparent disclosures, including risk management disclosures. The disclosures provide positive signal to shareholders about the effort done by IFIs to manage risk in their respective organisations.

Al-Maghzom et al. (2016) analysed the level of risk disclosure between Islamic and non-Islamic banks. They found that Islamic banks have lower disclosure-related risks than their non-Islamic counterparts. According to AlMaghzom et al. (2016), non-Islamic banks need to make a high level of disclosures in order to remain competitive in a society where people prefer Sharia-compliant products. Al-Baluchi (2006) showed that the level of voluntary risk disclosure in four Arab countries, namely, Bahrain, Qatar, Sudan and Jordan, increased after the implementation of AAOIFI standards. These countries mandated the implementation of AAOIFI standards as part of their national policies, which in turn increased the level of risk disclosure. Ullah (2013) examined the level of compliance towards AAOIFI standards in the related disclosures in the annual reports of Islamic banks in Bangladesh, a country in which the compliance with AAOIFI standards is not yet mandatory. The results show that the majority of sample banks have a high level of compliance with AAOIFI standards which leads to a high level of disclosures. The implementation of AAOIFI standards reduces the information asymmetry gap and provides transparent reporting practices (Ullah 2013).

In the current study, we predict that the implementation of AAOIFI standards with the presence of efficient corporate governance will lead a high level of risk disclosures. In other words, the implementation of AAOIFI standards in an organisation where the RMC is effective will improve the voluntary risk disclosures. Thus, we propose the following hypothesis: 
$H_{1 a}:$ The implementation of AAOIFI standards strengthens the relationship between RMC effectiveness and the level of voluntary risk disclosure amongst IFIs.

\section{SSB EFFECTIVENESS AND VOLUNTARY RISK DISCLOSURE}

Sharia Supervisory Board (SSB) strengthens the credibility of the Islamic financial system and has a significant influence in the Muslim community, being the end-user of Islamic financial products (Grassa, 2015). SSB has a fiduciary responsibility to certify Islamic products as being Sharia-compliant. Compliance to Sharia is the primary reason for the existence of Islamic institutions. Grassa (2015) argued that improvements in regulatory frameworks by SSB would be noticeable if the level of information disclosure is enhanced.

In general, SSB members should comprise of Sharia scholars or better known as ulamas. Not only do these scholars have in-depth knowledge of Sharia law, they also have a reputation of being the experts in Fiqh al-Muamalat. Sharia reputable scholars understand their obligation of providing transparent information to shareholders, which in turn generates a high level of trust to the Muslim community (El-Halaby \& Hussainey 2017). SSB is another corporate governance structure to protect shareholder interests and acts in a complementary manner with other corporate governance structure, such as Audit Committee and RMC (Chobpichien et al. 2008; Ward et al. 2009). The positive connection between SSB and voluntary risk disclosures is in line with the theoretical proposition that SSB mitigates agency conflicts by acting as an additional corporate governance layer that monitors managers, thereby resulting in increased disclosures (Elamer et al. 2019).

The large Sharia boards should comprise of scholars with various experiences and skills and different schools of thoughts, which lead to a satisfactory interpretation of the products and operations. Theoretically, agency theory depicts that a large board with diverse knowledge leads to a good monitoring role of the boards (Singh et al. 2004).

The current research aims to highlight the relationship between SSB effectiveness and the level of voluntary risk disclosure. We propose that when the effectiveness of SSB increases, the level of voluntary risk disclosure also increases. Based on agency theory, signalling theory and the above discussion, we propose the following hypothesis:

$\mathrm{H}_{2}$ : The effectiveness of SSB has a positive association with the level of voluntary risk disclosure.

\section{IMPLEMENTATION OF AAOIFI STANDARDS, SSB EFFECTIVENESS AND VOLUNTARY RISK} DISCLOSURES

In the Islamic world of finance, AAOIFI prepares, promulgates and interprets accounting and auditing standards for IFIs. AAOIFI carries out these objectives by following the principles of Sharia law and in conformity with the environment of IFIs. These standards enhance users' confidence in the information produced by these institutions and encourage investors to invest in these institutions.

The adoption of the AAOIFI standards amongst IFIs confirm the legitimacy of their existence in which they undertake socially acceptable activities and within specific boundaries (Wilmshurst \& Frost 2000). The AAOIFI standards provide a set of expectation of activities and allow stakeholders to judge the legitimacy of these activities. Prior studies showed a positive association between the implementation of the AAOIFI standards and the level of voluntary disclosure (Al-Baluchi 2006; Al-Maghzom et al. 2016).

Agency theory also explains the merits of the implementation of the AAOIFI standards. The theory argues that the principal-agent problem mainly arises because of information asymmetry between agents and principals (Barako et al. 2007). The implementation of AAOIFI standards mitigates this information asymmetry (Ullah 2013).

The AAOIFI standards (e.g. Standard No. 3) outline the aim of the Sharia audit to ensure the effectiveness of SSB. The implementation of AAOIFI standards increases the legitimacy of financial institutions, which in turn increases the effectiveness of SSB and helps the reduction of information asymmetry and the improvement of voluntary risk disclosure. The AAOIFI implementation seems to heighten the influence of SSB on an adequate level of risk disclosure. Thus, we propose the following hypothesis:

$H_{2 a}:$ The implementation of AAOIFI standards strengthens the relationship between the effectiveness of SSB and the level of voluntary risk disclosure amongst IFIs. 


\title{
RESEARCH FRAMEWORK
}

The proposed research framework of this study is presented in Figure 1. The dependent variable is Voluntary Risk Disclosure (VRD) and the independent variables are Risk Management Committee (RMC) and Sharia Supervisory Board (SSB) effectiveness. The implementation of AAOIFI standards is predicted to have a moderating role in the relationship between independent variables and dependent variable.

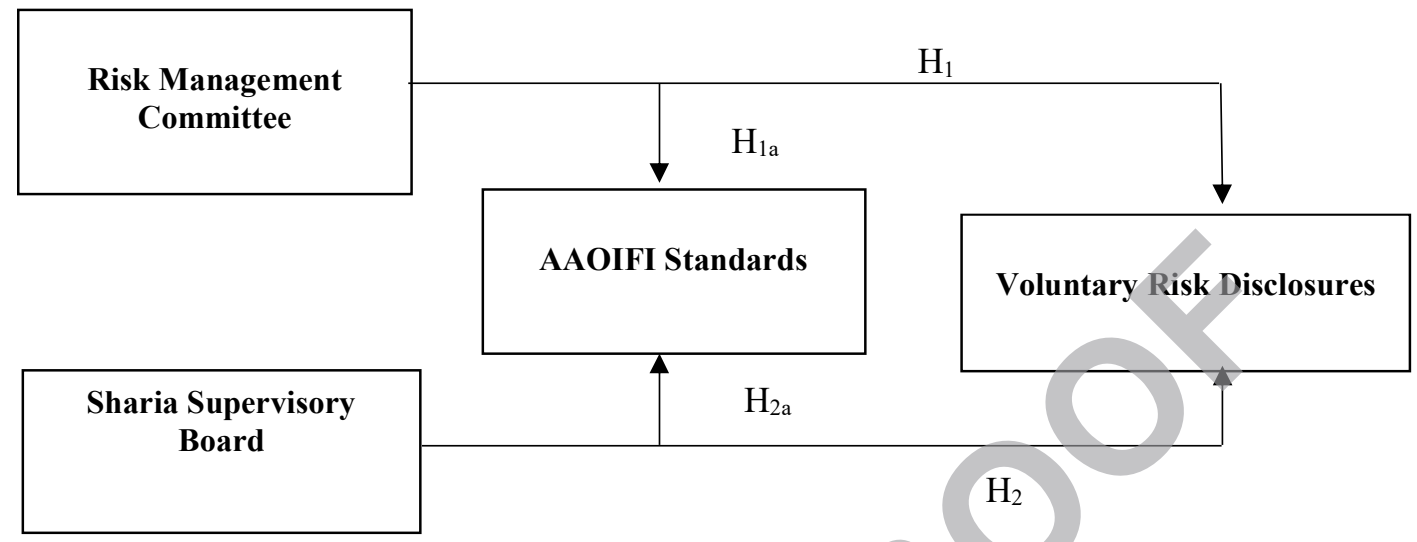

Figure 1 Conceptual framework

\section{RESEARCH METHODOLOGY}

\author{
SAMPLE SELECTION
}

The population of this study are all 185 firms listed on Saudi Arabian Stock Exchange (Tadawul). The study sample consists of all 49 firms listed in the financial sector (banks and insurance companies) for five years, $2013-2017$. The 2017 annual reports were the latest available annual reports at the time we collected the data for the study. This study focuses on Islamic financial institutions because the AAOIFI standards are only for the Islamic finance industry. There are 15 firms excluded from the sample study due to unavailability of data on the Sharia Supervisory Board (SSB). The final sample consists of 34 firms (167 firm-year observations), which represents 70 percent of the financial sector in Saudi Arabia. Thus, the sample represents the majority of financial firms listed in Tadawul, as shown in Table 1. Table 2 shows the sample distribution based on industry and year.

TABLE 1. Sample selection

\begin{tabular}{ll}
\hline Number of observations available for financial firms in Tadawul & 245 \\
from 2013 to 2017 & \\
Less: & 78 \\
\hline Firms with no information on SSB & 167 \\
\hline Total firm-year observations & 167 \\
\hline
\end{tabular}

TABLE 2. Sample distribution based on industry and year

\begin{tabular}{lcccccc}
\hline Industry & 2013 & 2014 & 2015 & 2016 & 2017 & Total \\
\hline Banks & 12 & 12 & 12 & 12 & 12 & 60 \\
Insurance & 21 & 21 & 21 & 22 & 22 & 107 \\
\hline Total & 33 & 33 & 33 & 34 & 34 & 167 \\
\hline
\end{tabular}

This study uses secondary data collected from financial database, Thompson Datastream, firm's website, and annual reports of Saudi financial firms. Prior studies (e.g. Gray et al. 1995; Neu et al. 1998) suggested that annual reports are the salient communicating information source for all stakeholders. Gray et al. (1995) argued that the annual report, as a communication channel, is the most important document of the reporting entity because it combines financial and other 
important information that all stakeholders can access. Thus, this study uses annual reports to extract information on voluntary risk disclosure practices, RMC characteristics, SSB characteristics, and other control variables.

\section{MEASUREMENT OF VARIABLES}

The dependent variable of this study is Voluntary Risk Disclosure (VRD). VRD is measured by constructing a risk disclosure index (e.g. Abdullah et al., 2015; Al-Maghzom et al., 2016). The following steps were taken to develop the index:

Step 1: A comprehensive review of prior studies to identify risk disclosure items (e.g. Abdullah et al., 2015; AlMaghzom et al., 2016; Lipunga, 2014). In this stage, this study identified 55 disclosure items.

Step 2: A review of AAOIFI (2014) standards and Islamic Financial Services Board (IFSB, 2013) to identify additional risk disclosure items. Five additional disclosure items were identified.

Step 3: These items were pilot tested to confirm the relevance and validity of disclosure items. A pilot test was conducted on three banks and three insurance companies for the year 2013 - 2017. This approach is consistent with Hertzog (2008), who suggests that at least $10 \%$ of the sample can be considered in a pilot study. The selection of these companies for the pilot test was based on companies' size (Elzahar \& Hussainey 2012). They proposed that company size is meaningfully connected with risk disclosures. A score of one is granted if the information is disclosed, and 0 otherwise.

According to the pilot test outcome, some risk disclosure items were not disclosed consistently by these six pilot companies. Hence, these items were omitted from the present research. The final risk disclosure items consist of 45 items grouped in seven categories. The detail is presented in Table 3.

TABLE 3. Risk disclosure items

\begin{tabular}{lccc}
\hline Categories & Initial Items & Final Items & Weight \\
& & After Pilot Test & \\
\hline Operational risk & 10 & 8 & $17.78 \%$ \\
Empowerment risk & 9 & 8 & $17.78 \%$ \\
Information processing and technology risk & 5 & 5 & $11.11 \%$ \\
Integrity risk & 3 & 3 & $6.67 \%$ \\
Strategic risk & 12 & 11 & $24.44 \%$ \\
Financial and other risks & 6 & 6 & $13.33 \%$ \\
Risks specific of Islamic institutions & 11 & 4 & $8.90 \%$ \\
Islamic standards & 4 & 0 & - \\
\hline Total & 60 & 45 & $100 \%$ \\
\hline
\end{tabular}

There are two independent variables; Risk Management Committee (RMC) effectiveness and Sharia Supervisory Board (SSB) effectiveness. This study used the 'bundles approach' method to measure RMC and SSB effectiveness. The bundles approach suggests that firm-level corporate governance mechanisms should consist of a 'bundle' - a sum of individual corporate governance characteristics that interact and substitute/complement each other (Chobpichien et al. 2008; Ward et al. 2009). Therefore, based on the 'bundles approach' method, this study constructed a composite measure to quantified the effectiveness of RMC, which takes a value of 0 - 4; with effectiveness varies from zero percent effective to 100 percent effective (see Table 4). The measure is a composite index of four key RMC characteristics, which are RMC size, RMC meeting, RMC independence and RMC qualifications. 
TABLE 4. Constructing the risk management committee effectiveness index

\begin{tabular}{|c|c|c|}
\hline $\begin{array}{l}\text { Attributes of RMC } \\
\text { Effectiveness }\end{array}$ & Score & References \\
\hline $\begin{array}{l}\text { RMC } \\
\text { Size }\end{array}$ & $\begin{array}{l}\text { "1" if the number of committee members is greater } \\
\text { than the sample median and " } 0 \text { " otherwise }\end{array}$ & Al-Hadi et al.( 2016) \\
\hline $\begin{array}{l}\text { RMC } \\
\text { Meeting }\end{array}$ & $\begin{array}{l}\text { "1" if the number of meetings held by the RMC } \\
\text { during the year is greater than the sample median, } \\
\text { and " } 0 \text { " otherwise. }\end{array}$ & $\begin{array}{l}\text { Abdullah et al. (2017); } \\
\text { Allini et al. (2016) }\end{array}$ \\
\hline $\begin{array}{l}\mathrm{RMC} \\
\text { Independence }\end{array}$ & $\begin{array}{l}\text { " } 1 \text { " if the majority of the member is independent, } \\
\text { and " } 0 \text { " otherwise. }\end{array}$ & Al-Hadi et al. (2016) \\
\hline $\begin{array}{l}\text { RMC } \\
\text { Qualifications }\end{array}$ & $\begin{array}{l}\text { " } 1 \text { " if at least one of the members is qualified (i.e. } \\
\text { has knowledge in risk management and } \\
\text { accounting/finance), and " } 0 \text { " otherwise. }\end{array}$ & Al-Hadi et al. (2016) \\
\hline
\end{tabular}

Likewise, a composite index was also developed to measure the effectiveness of SSB, which consist of four dichotomous attributes. It is constructed in such a way that it is bounded between 0 and 1 , as depicted in Table 5 . The higher the score, the greater is the effectiveness of the SSB. Four binary characteristics included in this measurement are SSB size, SSB meeting, SSB reputation and SSB cross-memberships.

TABLE 5. Constructing the Sharia Supervisory Board effectiveness score

\begin{tabular}{|c|c|c|}
\hline $\begin{array}{l}\text { Attributes of SSB } \\
\text { Effectiveness }\end{array}$ & Score & References \\
\hline SSB & "1" if the number of members on the & Elamer et. al. (2019); \\
\hline Size & $\begin{array}{l}\text { board is greater than the sample median } \\
\text { and " } 0 \text { " otherwise. }\end{array}$ & Nomran, at al. (2018) \\
\hline SSB & "1" if the number of meetings held by the & Kusuma \& Rosadi (2019) \\
\hline Meeting & $\begin{array}{l}\text { SSB during the year is greater than the } \\
\text { sample median, and " } 0 \text { " otherwise }\end{array}$ & \\
\hline $\begin{array}{l}\text { SSB } \\
\text { Reputation }\end{array}$ & $\begin{array}{l}\text { "1" if more than half of the members are } \\
\text { members of the senior council of Ulama, } \\
\text { and " } 0 \text { " otherwise. }\end{array}$ & $\begin{array}{l}\text { El-Halaby \& Hussainey } \\
\text { (2016) }\end{array}$ \\
\hline $\begin{array}{l}\text { SSB } \\
\text { Cross-memberships }\end{array}$ & $\begin{array}{l}\text { "1" if more than half of the members are } \\
\text { members in others SSBs, and "0" } \\
\text { otherwise. }\end{array}$ & $\begin{array}{l}\text { El-Halaby \& Hussainey, } \\
\text { (2016); Farook et al. (2011); } \\
\text { Nomran et al. (2018) }\end{array}$ \\
\hline
\end{tabular}

The implementation of AAOIFI standards is measured by dichotomous indicator; "1" if a particular sample of companies implements AAOIFI standards, and "0" otherwise. This study also employs five control variables; corporate governance, size, profitability, leverage and beta. The measurement of these variables are as follows: 
TABLE 6. Operational definition of control variables

\begin{tabular}{|c|c|c|c|c|}
\hline $\begin{array}{l}\text { Acrony } \\
\mathrm{m}\end{array}$ & Variable & Measurement & $\begin{array}{l}\text { Source of } \\
\text { Data }\end{array}$ & Prior studies \\
\hline CG-I & $\begin{array}{l}\text { Corporate } \\
\text { Governance } \\
\text { Mechanisms } \\
\text { index }\end{array}$ & $\begin{array}{l}\text { Un-weighted index of Corporate } \\
\text { governance score of } 7 \text { items (BOD } \\
=3 \text { items; Audit committee }=4 \\
\text { items) }\end{array}$ & $\begin{array}{l}\text { Data } \\
\text { Stream }\end{array}$ & $\begin{array}{l}\text { Al-Hadi et al. } \\
\text { (2016) }\end{array}$ \\
\hline ABig4 & Auditor type & $\begin{array}{l}\text { Dummy variable; } 1 \text { if auditor by a } \\
\text { big-four, } 0 \text { otherwise. }\end{array}$ & $\begin{array}{l}\text { Data } \\
\text { Stream }\end{array}$ & $\begin{array}{l}\text { El-Halaby \& } \\
\text { Hussainy (2016) }\end{array}$ \\
\hline SIZE & Firm size & Natural logarithm of total assets & $\begin{array}{l}\text { Data } \\
\text { Stream }\end{array}$ & $\begin{array}{l}\text { Elzahar \& } \\
\text { Hussainey (2012) }\end{array}$ \\
\hline PROF & Profitability & ROE (Return on Equity) & $\begin{array}{l}\text { Data } \\
\text { Stream }\end{array}$ & $\begin{array}{l}\text { Elzahar \& } \\
\text { Hussainey (2012) }\end{array}$ \\
\hline LVG & Leverage & $\begin{array}{l}\text { Leverage }= \\
\text { Long-term debt/ Total assets }\end{array}$ & $\begin{array}{l}\text { Data } \\
\text { Stream }\end{array}$ & $\begin{array}{l}\text { Abduilah et al. } \\
\text { (2015); Al- } \\
\text { Maghzom, (2016) }\end{array}$ \\
\hline Beta & Beta & $\begin{array}{l}\text { A firm's beta for at least twelve } \\
\text { months. }\end{array}$ & $\begin{array}{l}\text { Bloomberg } \\
\text { database }\end{array}$ & $\begin{array}{l}\text { Al-Hadi et al. } \\
\text { (2016) }\end{array}$ \\
\hline
\end{tabular}

\section{RESULTS AND ANALYSIS}

\section{DESCRIPTIVE STATISTICS OF VOLUNTARY RISK DISCLOSURE}

The descriptive statistics of voluntary risk disclosures (VRD) by both banks and insurance firms are depicted in Table 7 . VRD is categorised into seven categories, operations risk, empowerment risk, information processing and technology risk, integrity risk, strategic risk, financial and other risks, and risks specific to Islamic institutions.

TABLE 7. Descriptive statistics for VRD $(n=167)$

\begin{tabular}{|c|c|c|c|c|c|c|c|c|c|}
\hline VRD Categories & Min & $\operatorname{Max}$ & \multicolumn{6}{|c|}{ Mean } & SD \\
\hline Panel A: & & & \multicolumn{6}{|c|}{ Year } & \\
\hline & & & 2013 & 2014 & 2015 & 2016 & 2017 & All & \\
\hline Overall VRD & 0.1 & 0.64 & 0.34 & 0.36 & 0.40 & 0.42 & 0.42 & 0.39 & 0.09 \\
\hline \multicolumn{10}{|c|}{ Panel B: VRD Based on Sector } \\
\hline Banks $(n=60)$ & 0.24 & 0.64 & 0.36 & 0.39 & 0.43 & 0.46 & 0.49 & 0.43 & 0.10 \\
\hline Insurance $(n=107)$ & 0.16 & 0.53 & 0.33 & 0.34 & 0.39 & 0.40 & 0.39 & 0.37 & 0.08 \\
\hline \multicolumn{10}{|c|}{ Panel C: VRD Based on Categories } \\
\hline 1 Operations risk & 0.00 & 0.63 & 0.35 & 0.37 & 0.43 & 0.44 & 0.45 & 0.41 & 0.13 \\
\hline 2 Empowerment risk & 0.00 & 0.63 & 0.29 & 0.31 & 0.38 & 0.40 & 0.39 & 0.35 & 0.16 \\
\hline $\begin{array}{c}3 \text { Information processing } \\
\text { and technology risk }\end{array}$ & 0.00 & 1.00 & 0.42 & 0.48 & 0.58 & 0.59 & 0.59 & 0.53 & 0.34 \\
\hline 4 Integrity risk & 0.00 & 1.00 & 0.49 & 0.52 & 0.63 & 0.68 & 0.69 & 0.60 & 0.41 \\
\hline 5 Strategic risk & 0.09 & 0.91 & 0.40 & 0.40 & 0.42 & 0.44 & 0.44 & 0.42 & 0.18 \\
\hline 6 Financial and other risks & 0.00 & 0.50 & 0.28 & 0.30 & 0.32 & 0.32 & 0.33 & 0.31 & 0.11 \\
\hline $\begin{array}{l}7 \text { Risks Specific of Islamic } \\
\text { Institutions }\end{array}$ & 0.00 & 0.75 & 0.11 & 0.12 & 0.16 & 0.15 & 0.16 & 0.14 & 0.22 \\
\hline
\end{tabular}

Panel A of the Table shows that the mean value for overall voluntary risk disclosure (VRD) is 0.39 . This indicates that, on average, $39 \%$ of the risk disclosure items are disclosed in the annual report. The minimum and maximum value for VRD are $16 \%$ and $64 \%$ respectively. The level of VRD has been increasing over the years. This finding is supported by O'Connell (2016), which asserted that voluntary risk disclosures had been recently on a rising trend. A summary of the 
disclosures made by banks and insurance (Panel B) shows that the mean of disclosure is $43 \%$ and $37 \%$, respectively. In comparison with previous studies, Al-Maghzom et al. (2016) report a mean value of risk disclosure of $66 \%$ with a minimum value of $51 \%$ and a maximum value of $78 \%$, which makes it higher than the value obtained in this study.

Panel $\mathrm{C}$ shows the descriptive statistics based on the category of VRD. The highest reported risk disclosure category is Integrity Risk (IR), with a mean value of $60 \%$. This might be because integrity and aggressive enforcement against corruption are a main aspect of the Saudi Arabia Vision 2030. Hence, a lot of Saudi financial firms are evaluating and strengthening their competencies for integrity functions. On the other hand, the least reported risk disclosure category is the Risks Specific of Islamic Institutions (RSII) at 14\%.

\section{DESCRIPTIVE STATISTICS OF OTHER VARIABLES}

Table 8 shows the average Risk Management Committee (RMC) effectiveness index is 54\%, while the median is $50 \%$. Zango et al. (2015) reported that the mean and standard deviation of RMC are $61 \%$ and $16 \%$, respectively, using a similar unweighted scoring method.

The average of Sharia Supervisory (SSB) index is $38 \%$, while the median is $25 \%$. As SSB is one of the important corporate governance mechanisms in IFIs, the score implies that listed Saudi IFIs still need to improve their SSB quality to improve the overall corporate governance mechanisms among the Saudi financial firms. This is in line with the issuance of the Sharia Governance framework by Saudi Arabian Monetary Agency (SAMA) in 2020 to enhance the SSB quality.

TABLE 8. Descriptive statistics of continuous variables $(\mathrm{N}=167)$

\begin{tabular}{|c|c|c|c|c|c|}
\hline Variable & Mean & S. D & Min & Mdn & Max \\
\hline $\mathrm{RMC}$ & 0.54 & 0.27 & 0.00 & 0.50 & 1.00 \\
\hline SSB & 0.38 & 0.23 & & 0.25 & 1.00 \\
\hline \multicolumn{6}{|c|}{ Control variables: } \\
\hline CG-I & 0.51 & 0.19 & 0.29 & 0.43 & 1.00 \\
\hline Size & 22.51 & 2.56 & 18.78 & 21.32 & 26.83 \\
\hline ROE & 0.05 & 0.21 & -0.92 & 0.11 & 0.64 \\
\hline LVG & 0.06 & 0.03 & 0.01 & 0.06 & 0.20 \\
\hline Beta & 1.13 & 0.34 & 0.60 & 1.09 & 3.74 \\
\hline \multicolumn{6}{|c|}{$\begin{array}{l}\text { Where: RMC= Risk Management Committee Effectiveness, SSB= Shari'a Supervisory } \\
\text { Board Effectiveness, CG-I= corporate governance index, SIZE = Firm size (Natural } \\
\text { logarithm of total assets), ROE = Return on equity, LVG = Leverage (Long-term debt/ } \\
\text { total assets), Beta = risk which is calculated over } 12 \text { months by regressing the share price } \\
\text { against the respective market index. }\end{array}$} \\
\hline
\end{tabular}

Table 9 presents the frequency (\%) of dichotomous variables. The majority of the IFIs, 57 percent, implemented AAOIFI standards, and 81 percent of the sample are audited by a big-four audit firm.

TABLE 9. Descriptive statistics of dichotomous variable $(n=167)$

\begin{tabular}{lcc}
\hline Variables & $\mathbf{0}$ & $\mathbf{1}$ \\
\hline AAOIFI & 43 & 57 \\
Abig4 & 19 & 81 \\
\hline Where: AAOIFI= "l" if firm implements AAOIFI standards and " 0 " otherwise, Abig4= " 1 " if \\
IFIs is audited by Big4 audit firm and "0" otherwise. & \\
\hline
\end{tabular}

\section{MULTICOLLINEARITY}

Table 10 shows the Pearson correlation matrix of independent variables in this study. Overall, none of the variables have a correlation coefficient of more than 0.700 with any of the other variables. The highest correlation coefficient exists between SSD and Size (0.467) and between size and leverage (0.414). All reported correlation coefficient values in Table 10 are below the threshold level that is 0.700 . Thus, there are no multicollinearity issues among the variables (Field, 2017). 
TABLE 10. Pearson correlation matrix

\begin{tabular}{|c|c|c|c|c|c|c|c|c|}
\hline & RMC & SSD & AAOIFI & CG-I & Abig4 & SIZE & ROE & LVG \\
\hline SSD & $0.330 * * *$ & 1 & & & & & & \\
\hline AAOIFI & -0.012 & -0.104 & 1 & & & & & \\
\hline CG - I & $0.127 *$ & $0.290 * * *$ & 0.033 & 1 & & & & \\
\hline Abig4 & 0.054 & $0.169 * *$ & $-0.301 * * *$ & 0.045 & 1 & & & \\
\hline SIZE & $0.232 * * *$ & $0.467 * * *$ & $-0.364 * * *$ & $0.393 * * *$ & $0.387 * * *$ & 1 & & \\
\hline ROE & 0.065 & 0.102 & -0.068 & 0.014 & $0.156 * *$ & $0.360 * * *$ & 1 & \\
\hline LVG & $0.135^{*}$ & $0.218 * * *$ & $-0.128^{*}$ & $0.241 * * *$ & $0.192 * * *$ & $0.414 * * *$ & $-0.159 * *$ & 1 \\
\hline Beta & $-0.133 *$ & $-0.142 *$ & $0.220 * * *$ & $-0.147 *$ & -0.093 & $-0.390 * * *$ & $-0.144^{*}$ & $-0.142 *$ \\
\hline \multicolumn{9}{|c|}{$\begin{array}{l}\text { Where: } * * * p<.01 * * p<.05 * p<.10 \text {, respectively. } \\
R M C=\text { Risk Management Committee Effectiveness, SSB }=\text { Sharia Supervisory Board Effectiveness, AAOIFI= } \\
\text { implementation of AAOIFI standards, CG }-I=\text { corporate governance index, Abig4= Auditor type, SIZE }= \\
\text { Firm size (Natural logarithm of total assets), ROE = Return on equity, LVG = Leverage (Long-term debt/ } \\
\text { total assets), Beta = risk which is calculated over } 12 \text { months by regressing the share price against the } \\
\text { respective market index. }\end{array}$} \\
\hline
\end{tabular}

\section{RESULT OF MULTIPLE REGRESSION \\ EFFECTIVENESS OF RISK MANAGEMENT COMMITTEE}

Table 11 presents the multiple regression results of direct relationship between RMC effectiveness and VRD and the moderating role of AAOIFI in the relationship. Model 1 tests the direct relationship between RMC effectiveness towards VRD. The results show that there is a positive and significant relationship between the RMC effectiveness and the level of VRD (coef. $=0.102, \mathrm{t}=3.77, p<0.01$ ) at $1 \%$ level. The adjusted $\mathrm{R}^{2}$ is 0.50 , reflecting that 50 percent of the variation in VRD is explained by a set of predictor variables in Model 1. The direction of the coefficient indicates that a more effective RMC leads towards more VRD, and magnitude can be interpreted as, ceteris paribus, a one-unit increase in the effectiveness of RMC raises the level of voluntary risk disclosure by 0.10 units. The statistical relationship is in line with the first hypothesis of the study, which posits that there is a positive association between RMC effectiveness and level of VRD. This result is aligned with agency theory which proposes that the presence of effectiveness RMC reduces agency problem and information asymmetry by disseminating more risk information in the annual reports. Therefore, hypothesis $\mathrm{H}_{1}$ is accepted.

Signalling theory asserts that a company sends positive and/or negative signals to the market by undertaking certain positive and/or negative actions. Effective RMC influences the management to disclose more risk management information in a comprehensive manner. This behaviour sent positive signals about the company to the market (i.e. investors believe that the company is transparent and trustworthy).

This result is supported by the previous studies (Abdullah \& Chen 2010; Al-Hadi et al. 2016; Arowolo et al. 2017; Jia et al. 2019). These studies asserted that the risk management committee increases the level of risk disclosure and plays a role in improving the disclosure because such committees independently and regularly undertake prudent audits and assessments of relevant risks.

Model 2 (Table 11) tests a direct effect of RMC effectiveness and moderating effect of AAIOFI*RMC effectiveness towards VRD. The results show the RMC effectiveness is statistically significant to influence VRD (coef. $=$ $0.103, \mathrm{t}=3.300, p<0.01)$. The adjusted $\mathrm{R}^{2}$ has improved to 53 percent. However, the regression coefficient of interaction term, RMC*AAOIFI, is statistically not significant (coef. $=-0.060, \mathrm{t}=-1.210$ ), implying implementation of AAOFI standards does not strengthen the relationship between RMC effectiveness and VRD. 
TABLE 11. Results of AAOIFI as moderatoring variable between RMC and VRD

\begin{tabular}{lrr}
\hline Variables & VRD & \multicolumn{1}{c}{$\begin{array}{c}\text { VRD } \\
\text { Model 2 }\end{array}$} \\
\hline RMC & $\mathbf{0 . 1 0 2 ( 3 . 7 7 0 ) * * *}$ & $\mathbf{0 . 1 0 3 ( 3 . 3 0 0 )} * *$ \\
AAOIFI & $-0.03(-1.680) *$ & $0.002(0.070)$ \\
RMC*AAOIFI & & $\mathbf{- 0 . 0 6 0 ( - 1 . 2 1 0 )}$ \\
CG- INDEX & $0.0314(0.470)$ & $0.046(0.760)$ \\
A big4 & $0.013(0.440)$ & $0.003(0.130)$ \\
SIZE & $0.010(0.410)$ & $0.006(0.270)$ \\
ROE & $0.047(2.350) * *$ & $0.054(2.750) * * *$ \\
LVG & $0.434(1.260)$ & $0.478(1.240)$ \\
Beta & $-0.021(-1.460)$ & $-0.021(-1.440)$ \\
Constant & $0.050(0.08)$ & $0.149(0.31)$ \\
\hline Adjusted $\mathrm{R}^{2}$ & 0.50 & 0.53 \\
$N$ & 167 & 167 \\
\hline Where: $* * * \mathrm{p}<.01 * * \mathrm{p}<.05 * \mathrm{p}<.10$, respectively. & &
\end{tabular}

The insignificant role of AAOIFI standards implementation is not what the study has predicted. The insignificant findings could be due to the non-mandatory nature of its implementation. This phenomenon can have a significant influence on the results of the study. As presented earlier in Table 9, only 57 percent of the sample firm implemented AAOIFI standards. Since the nature of the implementation is still voluntary, the sample firm may have not implemented the full extent of the standards. Therefore, AAOIFI standard implementation has not made any difference in the VRD and does not strengthen the relationship between RMC and VRD. Therefore, hypothesis $\mathrm{H}_{1} \mathrm{a}$, which posits that the implementation of AAOIFI standards strengthens the relationship between RMC effectiveness and level of VRD, is not accepted.

\section{EFFECTIVENESS OF SHARI'A SUPERVISORY BOARD}

Model 3 in Table 12 presents the results of the direct relationship between SSB effectiveness and the level of VRD. The results show that there is a significant and positive relationship between SSB effectiveness and the level of VRD (coef. $=$ $0.140, \mathrm{t}=4.110, p<0.01)$ at $1 \%$ level. The coefficient value of 0.140 implies that a unit increase in SSB effectiveness, ceteris paribus, leads to an increase of VRD level by 0.140 points. Hence, the statistical relationship is in line with what is conjectured in hypothesis $\mathrm{H}_{2}$ - there is a positive association between the effectiveness of SSB and VRD level. The adjusted $\mathrm{R}^{2}$ show that 53 percent of the variation in VRD is explained by a set of predictor variables in Model 3 .

The results are consistent with previous finding (Elamer et al., 2019), which also entail the positive effect of SSB in the Gulf and MENA region. Moreover, the results are consistent with the agency theory that proposes the effectiveness of SSB influences managers to make a high level of voluntary risk disclosures to avoid potential conflict of interests. The result is also well-supported by the legitimacy theory, which states that the disclosures can be used as a possible tool to decrease regulatory pressures from government and community (Zadeh \& Eskandari 2012) and improve IFIs legitimacy.

TABLE 12. Results of AAOIFI as moderatoring variable between SSB and VRD

\begin{tabular}{lrc}
\hline Dependent Variable & \multicolumn{1}{c}{$\begin{array}{c}\text { VRD } \\
\text { Model 3 }\end{array}$} & \multicolumn{1}{c}{$\begin{array}{c}\text { VRD } \\
\text { Model 4 }\end{array}$} \\
\hline SSB & $\mathbf{0 . 1 4 0}(\mathbf{4 . 1 1 0} * * *$ & $0.073(1.610)$ \\
AAOIFI & $0.019(1.250)$ & $0.025(1.150)$ \\
SSB*AAOIFI & & $\mathbf{- 0 . 0 2 7}(\mathbf{- 0 . 6 2 0})$ \\
CG- INDEX & $-0.001(-0.020)$ & $-0.023(-0.490)$ \\
A big4 & $0.015(0.680)$ & $0.022(0.980)$ \\
SIZE & $0.006(0.780)$ & $0.011(1.120)$ \\
ROE & $0.022(1.12)$ & $0.017(0.950)$ \\
LVG & $-0.055(-0.160)$ & $0.002(0.010)$ \\
Beta & $-0.020(-1.420)$ & $-0.017(-1.340)$ \\
Constant & $0.143(-0.150)$ & $0.071(0.300)$ \\
\hline N & 167 & 167 \\
Adjusted $\mathrm{R}^{2}$ & 0.53 & 0.62 \\
\hline Where: $* * * p<.01 * * p<.05 * p<.10$, respectively. &
\end{tabular}

Model 4 (Table 12) tests the moderating role of AAOIFI standard implementation (SSB effectiveness*AAOIFI) in the relationship between SSB effectiveness and VRD. The results show that SSB effectiveness and AAOIFI (SSB * 
AAOIFI) interaction is not statistically significant (coef. $=-0.027, \mathrm{t}=-0.620$ ), implying AAOIFI does not strengthen the relationship between SSB effectiveness and VRD. The hypothesis $\mathrm{H}_{2}$ a, which posits that the implementation of AAOIFI standards strengthens the relationship between the effectiveness of SSB and VRD level, is not accepted.

These insignificant results could be explained by the legitimacy theory. Legitimacy theory asserts that an organisation exists if it is legitimised. Both AAOIFI standards and SSB complement each other in promoting Islamic principles of doing business. Thus, if one is already effective, the other one is not needed. Moreover, compliance with AAOIFI standards is likely to mitigate the risk level in IFIs, leading to a low level of risk disclosure. Although the presence of AAOIFI means increased legitimacy in financial institutions, it does not necessarily contribute to the increase in voluntary risk disclose, especially when the disclosure is already high with effective SSB.

\section{CONCLUSION}

Risk management information by any business entities is essential information sought by many interest parties, especially shareholders and investors, to confirm their investment decision. However, the current risk management reporting level is still low and considered insufficient to be relied on to make sound economic decisions. Mandatory risk management reporting is insufficient to fulfil information need by investors and stakeholders. Thus, voluntarily risk information reporting in companies' annual reports are needed to fill in the risk information gap.

This study reinvestigates the relationship between RMC and SSB effectiveness on the level of voluntary risk disclosure in Saudi financial firms for the year 2013 to 2017. This study also seeks to examine whether the implementation of AAOIFI standards strengthens the relationships between RMC and SSB effectiveness with the level of voluntary risk disclosure in Saudi financial firms. The study proposes that AAOIFI standards implementation can add legitimacy and credibility of IFIs, being the accounting and auditing standards setter, aims to harmonise IFIs practices and reporting. The standards promote transparent reporting practices of IFIs by requiring a minimum level of disclosures, therefore, reducing information asymmetry gap. Additionally, the AAOIFI also published governance standards on Sharia compliance and supervision process and framework. The standards specified the establishment of Sharia Supervisory Board (SSB), to certify and monitor all financial contracts, transactions, and actiyities of IFIs on behalf of depositors, shareholders, and stakeholders.

The results show that RMC and SSB's effectiveness have a positive impact on the level of voluntary risk disclosure. However, the results show that AAOIFI standard implementation cannot strenghthen the relationship. This finding is contradicting the expectation. This could be that the implementation of AAOIFI in Saudi is still not mandatory. There are IFIs who must not have taken the AAOIFI implementation to the full extent. Additionally, both AAOIFI standards and SSB are said to be complementing each other in promoting Islamic principles of doing business and thus, if one is already effective, the other one is not needed

The study enhances the current understanding of the importance of corporate governance mechanisms to reduce the information asymmetries between inside and outside stakeholders. This study provides this perspective from agency theory that effective governance mechanisms (such as RMC and SSB) help to influence high level of voluntary risk disclosure that mitigating agency problem by reducing information asymmetry between inside and outside stakeholders which enhances firm's performance. Thus, these research findings provide beneficial input to managerial teams and corporate leaders on the effect of effective corporate governance to improve more transparency in reporting practices. In addition, results from this study are expected to have important policy implications. Regulatory bodies, such as central banks, can have better understanding on the importance of effective RMC and SSB on voluntary risk disclosures. Additionally, the AAOIFI standards implementation should be considered to be made mandatory as the non-mandatory implementation does not improve the disclosure of risk reporting.

This study has certain limitations. The sample of this study is drawn from listed Saudi financial companies and thus, its findings may not be generalised to other business sectors. Secondly, this study measures the level or quantity of voluntary risk disclosure and ignore its quality. This opens opportunity for future research as well. Future research can also be conducted for the non-financial sector with a larger sample size by including other Islamic countries in the world.

\section{ACKNOWLEDGEMENTS}

The authors gratefully acknowledge the financial support by the Fundamental Research Grant Scheme (FRGS/1/2017/SS01/UKM/02/6) from the Ministry of Higher Education (MOHE).

\section{REFERENCES}

AAOIFI. 2016. available at: www.aaoifi.com (accessed 1 Dec 2020)

Abdullah, M., \& Chen, L. 2010. The Association Between Committees Responsible for Risk Management and the Disclosure Level of Financial Instruments Information Among Listed Companies in Malaysia. Unpublished Master. 
Diss., University of Gothenburg, Sweden.

Abdullah, M., Abdul Shukor, Z., Mohamed, Z. M., \& Ahmad, A. 2015. Risk management disclosure: A study on the effect of voluntary risk management disclosure toward firm value. Journal of Applied Accounting Research 16(3): 400432.

Abdullah, M., Shukor, Z. A., \& Rahmat, M. M. 2017. The Influences of Risk Management Committee and Audit Committee towards Voluntary Risk Management Disclosure. Jurnal Pengurusan (UKM Journal of Management) 50: $83-95$.

Adamu, MU. 2013. The Need for Corporate Risk Disclosure in the Nigerian Listed Companies Annual Reports. IOSR Journal of Economics and Finance 1 (6): 15-21.

Al-Baluchi, A. E. 2006. The impact of AAOIFI standards and other bank characteristics on the level of voluntary disclosure in the annual reports of Islamic banks. PhD. Diss., University of Surrey, United Kingdom.

Al-Hadi, A., Hasan, M. M., \& Habib, A. 2016. Risk committee, firm life cycle, and market risk disclosures. Corporate Governance: An International Review 24 (2): 145-170.

Allini, A., Manes Rossi, F., \& Hussainey, K. 2016. The board's role in risk disclosure: an exploratory study of Italian listed state-owned enterprises. Public Money \& Management 36 (2): 113-120.

Al-Maghzom, A., Hussainey, K., \& Aly, D. 2016. Corporate Governance and Risk Disclosure: Evidence from Saudi Arabia. Corporate Ownership and Control Journal 13 (2):145-166.

Alman, M. 2012. Shari'ah supervisory board composition effects on Islamic banks' risk-taking behavior. Journal of Banking Regulation 14: 134-163.

Archer, S., Karim, R. A. A., \& Al-Deehani, T. 1998. Financial contracting, governance structures and the accounting regulation of Islamic banks: an analysis in terms of agency theory and transaction cost economics. Journal of Management and Governance 2(2): 149-170.

Arowolo, R. O., Ahmad, A. C., \& Popoola, O. M. J. 2017. Effect of Risk Management Committee on Monitoring Mechanisms. Indian-Pacific Journal of Accounting and Finance 1(2): 38-49.

Barako, D. G., Hancock, P., \& Izan, H. 2007. Determinants of voluntary disclosures in Kenyan companies annual reports. African Journal of Business Management 1(5): 113-128.

Baron, R.M., \& Kenny, D.A. 1986. The moderator-mediator variable distinction in social psychological research: Conceptual, strategic, and statistical considerations. Journal of Personality and Social Psychology 51(6): 11-73.

Cabedo, J. D., and Tirado, J. M. 2004. The disclosure of risk in Financial Statements. Accounting Forum 28: 181-200.

Chobpichien, J. , Haron, H., \& Ibrahim, D. 2008. The quality of board of directors, ownership structure and level of voluntary disclosure of listed companies in Thailand. Euro Asia Journal of Management 3(17): 3-39.

Elamer, A. A., Ntim, C. G., Abdou, H. A., \& Pyke, C. 2019. Sharia supervisory boards, governance structures and operational risk disclosures: Evidence from Islamic banks in MENA countries. Global Finance Journal 46: 1-44.

El-Halaby, S., \& Hussainey, K. 2016. Determinants of compliance with AAOIFI standards by Islamic banks. International Journal of Islamic and Middle Eastern Finance and Management (9): 1-22.

Elzahar, H., \& Hussainey, K. 2012. Determinants of narrative risk disclosures in UK interim reports. The Journal of Risk Finance 13(2): 133-147.

Farahnaz Orojali Zadeh, Alireza Eskandari. 2012. Firm Size as Company's Characteristic and Level of Risk Disclosure: Review on Theories and Literatures. International Journal of Business and Social Science 3(17): $9-17$.

Farook, S., Kabir Hassan, M., \& Lanis, R. 2011. Determinants of corporate social responsibility disclosure: The case of Islamic banks. Journal of Islamic Accounting and Business Research 2(2): 114-141

Field, A. 2017. Discovering statistics using SPSS. 3rd Edition. London: Sage.

Grassa, R. 2015. Shariah supervisory systems in Islamic finance institutions across the OIC member countries. Journal of Financial Regulation and Compliance 23 (2): 135-160

Gray, R., Kouhy, R., \& Lavers, S. 1995. Corporate social and environmental reporting: a review of the literature and a longitudinal study of UK disclosure. Accounting, Auditing \& Accountability Journal 8(2): 47-77.

Hamza, H. 2013. Shari'a Governance in Islamic Banks: Effectiveness and Supervision Model. International Journal of Islamic and Middle Eastern Finance and Management 6(3): 226-237.

Hertzog, M.A. 2008. Considerations in determining sample size for pilot studies. Research in nursing \& health 31(2): 180191.

Jensen, M. \& Meckling, W. 1976. Theory of the firm: Managerial behavior, agency costs and ownership structure. Journal of Financial Economics 3: 305-360.

Jia, J., Li, Z., \& Munro, L. 2019. Risk management committee and risk management disclosure: evidence from Australia. Pacific accounting Review 31(3): 438-461

Kusuma, M., \&Rosadi, S. 2019. Islamic Corporate Governance and Islamic Banking Financial Performance. Journal of Finance and Islamic Banking 1(2): 164-179.

Lipunga, A. M. 2014. Risk disclosure practices of Malawian commercial banks. Journal of Contemporary Issues in Business Research 3(3): 154-167.

Neu, D., Warsame, H., \& Pedwell, K. 1998. Managing public impressions: Environmental disclosures in annual reports. Accounting, organisations and society 23(3): 265-282. 
Nomran, N. M., Haron, R., \& Hassan, R. 2018. Shari'ah supervisory board characteristics effects on Islamic banks' performance: evidence from Malaysia. International Journal of Bank Marketing 36(2): 290-304.

Rini. 2014. The effect of audit committee role and Shari'a supervisory board role on financial reporting quality at Islamic banks in Indonesia. Journal of Economics, Business, and Accountancy 17(1): 145-156.

Safieddine, A. 2009. Islamic financial institutions and corporate governance: New insights for agency theory. Corporate Governance: An International Review 17(2): 142-158.

Singh, M. Mathur, I. and Gleason, K. 2004. Governance and performance implications of diversification strategies: evidence from large US firms. Financial Review 39 (4): 489-526.

Thijs, J. P. 2016. Risk Management in Islamic Banking. Bank Islam Malaysia Berhad. Retrieved March 18, 2018, from http://www.bankislam.com.my/en/Documents/Shari'a/RiskMgmtinIslamicBkg.pdf

Ullah, M. H. 2013. Compliance with AAQIFI Guidelines in General Presentation and Disclosure in the Financial Statements of Islamic Banks in Bangladesh. International Journal of Social Science Research 1(2): 111-123.

Ward, A. J., Brown, J. A., \& Rodriguez, D. 2009. Governance bundles, firm performance, and the substitutability and complementarily of governance mechanisms. Corporate Governance: An International Review 17(5): 646-660.

Warda Alsheikh, Romlah Jaffar, Mohamat Sabri Hassan, Maizatulakma Abdullah \& Awatif Alsheikh 2020. Islamic Corporate Governance and Voluntary Risk Reporting in Saudi Arabia: The Role of Corporate Life Cycle, Test Engineering and Management Journal 83: 5046 - 5061.

Wilmshurst, T. D., \& Frost, G. R. 2000. Corporate environmental reporting: a test of legitimacy theory. Accounting, Auditing \& Accountability Journal 13(1): 10-26.

Zango, A. G., Kamardin, H., \& Ishak, R. 2015. Risk management committee effectiveness and International Financial Reporting Standards 7 (IFRS7) compliance by listed banks in Nigeria. International Journal of Advanced Research 3(6): 160-165.

${ }^{1}$ It is the knowledge of the legal rule on al-Muamalat rulings governing commercial transactions.

${ }^{2}$ The Saudi Vision 2030 is a post-oil plan for the Kingdom of Saudi Arabia announced on April 25, 2016.

Romlah Jaffar*

Fakulti Ekonomi dan Pengurusan

Universiti Kebangsaan Malaysia

43600 UKM Bangi, Selangor, MALAYSIA

E-mail: romlah@ukm.edu.my

Warda Al Sheikh

Makkah Community College

Umm Al-Qura University

Makkah, Saudi Arabia,

Fakulti Ekonomi dan Pengurusan

Universiti Kebangsaan Malaysia

43600 UKM Bangi, Selangor, MALAYSIA

Email:whshiakh@uqu.edu.sa

Mohamat Sabri Hassan

Fakulti Ekonomi dan Pengurusan

Universiti Kebangsaan Malaysia

43600 UKM Bangi, Selangor, MALAYSIA

E-mail: msabri@ukm.edu.my

Maizatulakma Abdullah

Fakulti Ekonomi dan Pengurusan

Universiti Kebangsaan Malaysia

43600 UKM Bangi, Selangor, MALAYSIA

E-mail: maizatul@ukm.edu.my

*Corresponding author 